\title{
MUALAF CENTER DESIGN AS AN IMPLEMENTATION OF PSYCHOLOGICAL AND ECONOMICAL EFFECT FOR MUALAF IN MALAYSIA
}

| Received May 16th 2016 | Accepted June 17th 2016 | Available online June 30th 2016 |

DOI http://dx. doi.org/10.18860/iia.v4i1.3466 |

\author{
Ansfiksia Eka Poetra Yudha \\ Architecture Department \\ UIN Maulana Malik Ibrahim \\ Malang, Jawa Timur, Indonesia \\ eka.ansfiksia@gmail.com \\ Ernaning Setiyowati \\ Architecture Department \\ UIN Maulana Malik Ibrahim \\ Malang, Jawa Timur, Indonesia \\ ernaning@arch.uin-malang.ac.id
}

\begin{abstract}
Mualaf is the term to represent people who just moves to Islam from other religion. Mualaf Center is an important place for mualaf to get information about Islam. There are some reasons and factors that make a not-Moslem hesitates about their religion and decides to move to Islam. These circumstances make them need a psychological and economical guidance as the effects after they become mualaf. There are $6.3 \%$ from total citizen becomes mualaf in Malaysia. This number is in the not-Moslem society, so the effect of becoming mualaf can be perceived especially the psychological and economical effects. Therefore, mualaf center can be a good place for mualaf to get a guidance and consultation. This paper discusses mualaf center design based on the issues and problems about mualaf in Malaysia. The aim of this study is to find a recommendation design for mualaf center based on the issue in Malaysia. The discussion uses literature study method which will be analyzed descriptively. So the result of the discussion is a summary of design criteria that proper with the issue. This design criterion will be integrated using relevant design theme approach, i.e. sustainable architecture. The design criteria that is already integrated is the availability of guidance and consultation facilities, also entrepreneur practice facility toward psychological and economical effects. With by the guidance in this mualaf center the mualaf will be capable of adapting to the social environment around them and also can rebuild their economic life as before in islamic ways.
\end{abstract}

KEYWORDS:

Mualaf, mualaf center; social; economic; psychology; sustainable architecture

\section{INTRODUCTION}

The term mualaf comes from two words, i.e 'Allafa' which means submissive, and 'Alifahu' which means complaint [1]. The combination of those two words gives a definition that mualaf means to change or to make people change their beliefs. In other words, mualaf is those who enunciate Shahadat and included to the category of Moslem that needs guidance and attention from other Moslem [2]. In the process of fathom the Islam, the mualaf will find some steps that need knowledge, support, patient, advice, and motivation to face every step, until they reach serenity to undergo the religion [2].

People needs to face three phase to be a mualaf, i.e. the first phase to be Moslem, the continuity of life in Islamic ways, and the phase to strengthen the faith. The first phase to be Moslem is divided into six steps, i.e. make sure to know the meaning of being Moslem, read Qur'an, discuss and consult with the religious leaders, enunciate Shahadat by themselves, then enunciate shahada again in front of two testifiers to be a legal Moslem, and last purify them by taking a bath.

Beside the six first steps, there is another step that should be taken by the male mualaf, which is khitan or circumcision. It is a part of maintaining the human purity [3].

Rasulullah shallallahu 'alaihi wa sallam said, "There is five circumstance in Fitrah: khitan, genital hair shaving, nail cutting, armpit hair whipping out, and upper lips hair shaving" [4]. Moreover, there is another step to legalize the religion for mualaf, by reporting it to the government to get a new identity card.

After all of the first phase is done, the mualaf starts to enter the second phase, which is to live a life under Islamic ways and rules. The second phase is divided into five steps, i.e. fulfill the obligation in Islam, obey the Moslem ethics, understand and do the principles of Islam, and last, believe the faith principles. The last phase to be a mualaf is to strengthen the faith to Allah SWT by reading Qur'an, learning the Islamic laws, and choose one of the figh genres, and fix the behavior to be a better person.

In Malaysia, after a person becomes a mualaf, they have rights to get zakat, circumcision (for male), worship equipment, and funeral. These rights have been assigned by Majlis or Jabatan Agama Islam in Malaysia. Moreover, mualaf can also get help for racist life, a place for living, medicine, marriage, and Islamic education. These rights are followed by the obligation that should be done by mualaf, such as join the class for Islamic guidance.

A person has to face some consequences to living a life as mualaf,, one of them is to be an abandoned person in a not-Moslem majority realm. This incident happened at Kampung Bukit Yong region, where there was a Moslem family from Siam descendant.This family lived in Buddhism community. 
They were ignored by the community after they become mualaf.

This incident becomes a worrying incident for the citizens that has a willingness to be a mualaf. Because it can hamper a person's life and his family to socialize with the surrounding. The research by Departemen Pendidikan Dakwah dan Kepemimpinan (JPDK), Fakultas Studi Islam, Universitas Kebangsaan Malaysia (UKM) found the amount of mualaf that is unregistered in the Departemen Agama Islam caused by some factors [5]. This is proved in a census that estimated the total population of Malaysia citizens is 29,6 million (July 2013). The census showed that 61,3\% from the population were Moslem; $19,8 \%$ is Buddha, 9,2\% is Christian, $6,3 \%$ in Hindu, and $1,3 \%$ are Confucianism, Taoism, or another traditional Chinese religion/belief. Meanwhile, the Melayu ethnic Moslem that has been Moslem since they were born was about $55 \%$ of population [6]. It shows that mualaf population in Malaysia was about $6.3 \%$ or 1.864 .800 person.

Factors that has a contribution for the religious changing in Malaysia is divided into two factors, i.e. internal and external. The internal factors are the less of religious education, marriage, divorce, parents, and economic life. Meanwhile, the external factors are the environment, friends, religious missionary movements, law flexibility, religious administration, Islamic educational system, and discrimination [7]. These factors create conversion patterns, like a) majority of the mualafs come from Sabah and belongs to other races found in Malaysia such as Iban, Asli, Myanmar, Kadazan and Thai, b) many of them are unemployed despite having adequate academic level, c) majority of the new mualafs agree that they get the first source of information regarding Islam from people who are close to them like family members, friends, colleagues and neighbours, d) majority of the new mualafs associate their conversion process with the affectional pattern, followed by the intellectual pattern and lastly the mystical pattern. This coincides with the first source of information they obtain regarding Islam [8].

From this condition, it can be said that Malaysia needs to have a mualaf center that can solve the social and economic problems. The design approach that is suitable for the issue is sustainable building, which one of the consideration of the designing process is the connection between the social life of the society. In another word, there is a term sustainable community which means a sustainable social relationship, not only in the building context but also in interior design. So the application of sustainable architecture in the design of mualaf center should optimize the social and economic impact, but decrease the negative impact of the environment. The sustainable design emphasizes to the search of a design solution that is balanced to the environmental problems, comfort, aesthetic, and also the cost. Automatically, the sustainable design is related to the strategy and technology that has a low impact on the environment and fix the comforts of the environment quality, such daylight, indoor air quality, natural ventilation, energy efficiency, minimize the construction waste, water conservation, solid waste management, renewable energy, natural landscape, and site preservation. Therefore, sustainable design is the one that has the capability to handle the condition related to the global environment crisis, the rapid growth of economic activity and human population, natural resources depression, ecosystem failure, and the loss of human biodiversity.

The integration between issue, conversion system and design theme can create the mualaf center that is suitable for the mualaf needs. This recommendation design can be used as references to build a center for mualaf to get an information and guidance about Islam to strengthen the faith and the economic life of the mualafs. Moreover, the design can be expected to generate mualafs which are kaffah, istiqomah, and prosperous.

\section{METHODS}

The method used in this study is literature study related to the object and design theme. Data source is got from literature study related to the social and economic issue of mualaf. The data then be analyzed descriptively so can produce the design criteria which solve mualaf problem and support their life.

\section{DISCUSSION}

There are some points that can be a reference to design a mualaf center based on the data and facts of mualaf in Malaysia, i.e:

1. Mualaf Needs a Continuity of Education, Support, Patience, Counsel, and Motivation.

The people that proceed to be a mualaf has a confusing mind shock. It is because there is some indecision towards their previous religion, so they will have some questions that need to be answered to direct them to a better life. Not only before they become mualaf, but also in the life after mualaf, they will still be uncertain and worried about continuing their life as Moslem. These people need a place where the religious leader can give a guidance. Just like what was done in HBMI (Himpunan Bina Mualaf Indonesia), where they have a guidance process that is divided into some steps, i.e step before Shahadat, Shahadat, and after Shahadat. It is different with the guidance handled by al-Falah mosque in Surabaya Indonesia. AlFalah not only guides a mualaf to enunciate Shahadat but also what mualaf should do next. They will guide the mualaf to consult the guidance schedule. The functions of this guidance are: (1) Healing function. This function is to help mualaf that has a problem, whether it comes from personal, social, or the other; (2) Adaptation function. This is to help mualaf to adapt with the new identity and environment; (3) Maintenance function. This function is to facilitate mualaf to avoid the condition that probably will cause them hesitate or lost their faith. One of the targets of al-Falah is to build the Islamic character so the mualaf will not be tempted to go back to the old environment. The same thing is also done by ICC (The Islamic Cultural Center) New York. ICC has a mission to lightened America with the right education of Islam, as well as Islamic ideology, philosophy, and culture; They give a 
religious education to the Moslem community in America, as well as the right religious opinion, the Islamic law, and also Islamic social and culture; they promote the good understanding and good relationship between Moslem and not-Moslem.

There are many ways that are given by each institution to give an education and knowledge about Islam. It will give a big benefit for the life of mualaf to socialite. The biggest part of the knowledge, advice and support come from the guidance for mualaf. Moreover, the mualaf can also consult individually to tell the problem they have been through.

\section{The Need of Facilities to Build the Psychology and Economic Life}

The availability of the facility depends on the user needs. The things needed by mualaf in Malaysia is everything related to the process of becoming mualaf. It is related to the phase of being Moslem that needs a counseling to do each phase they will do. The facilities can be found in the al Falah mosque Surabaya. The area of the al-Falah mosque according to the north and south terrace is $1.264 \mathrm{mz}$. it is divided into 9 rooms, i.e;

1. Auditorium (recitation room), $56 \mathrm{m2}$;

2. Administration office, including meeting room, 40 $\mathrm{m} 2$;

3. Library, $56 \mathrm{m2}$;

4. Women pray room, $80 \mathrm{~m} 2$;

5. Balcony, $28 \mathrm{~m} 2$;

6. Front terrace, $21 \mathrm{~m} 2$;

7. North, south, and east side yard with roof $365 \mathrm{~m}$;

8. Wudu room including 3 bathrooms, 3 toilets, and 75 faucets;

9. Garden on the west side of the mosque, $965 \mathrm{mz}$.

It shows that al-Falah mosque is not only functional as a prayer room, but also be functional as a guidance for mualaf. The mualaf guidance is established under al-Falah Mosque Foundation that has some duties, i.e: give a service to pledge to be a Moslem, give a service to guide to pray and reading Qur'an, and give a service of consultation for mualaf.

Many mualaf consults about their life after being mualaf. They sometimes being expelled from their home. If this happens, the al-Falah foundation will help them to find a new place for living.

Meanwhile, HBMI (Himpunan Bina Mualaf Indonesia) also does the same. But in addition to doing a religion guidance, they also give an economic guidance.

In the economic guidance, HBMI gives some skill courses for mualaf. They do not have to worry about the business funding. All of the business must be done under HBMI, they may not doing business on their own.

Different from other institution, Islamic Cultural Center New York is planned to be an Islamic institution that has a mosque, a school, a library, a classroom, a museum, and a living place for the leader. The Islamic Cultural Center that located in Manhattan has some services and activities besides prayers and Friday prayer, comprise answering questions about the religion via letters, answering questions via telephone from Moslem and not-Moslem, attending the government invitation, etc [9].

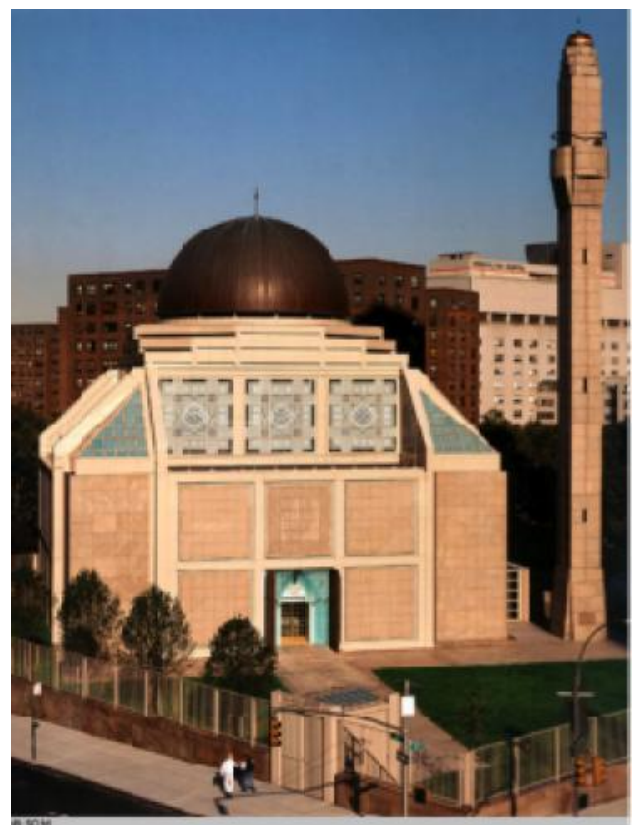

Figure 1. ICC Building [10]

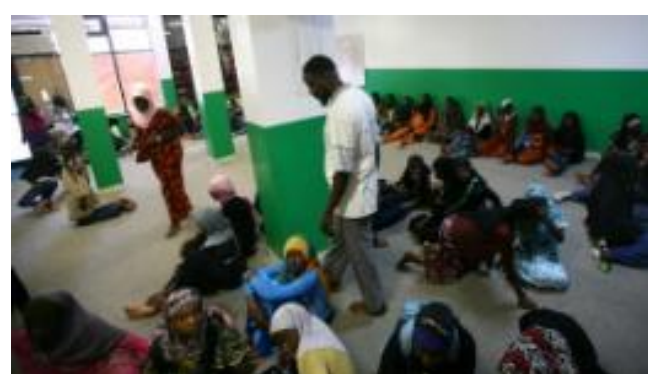

Figure 2. The Islamic Cultural Center (ICC) offers services and programs, like summer camp, in an emergency place in Bronx since the fire in 2009 [11]

This services also include receiving visitor from many educational institution, answering invitation from school to give some Islamic speech, participating in group discussion in religion cross meeting, giving religious guidance, marrying people, family counseling, helping people to solve their marriage problem, watching the procedure and funeral services, promoting social relationship, and doing some cultural activities.

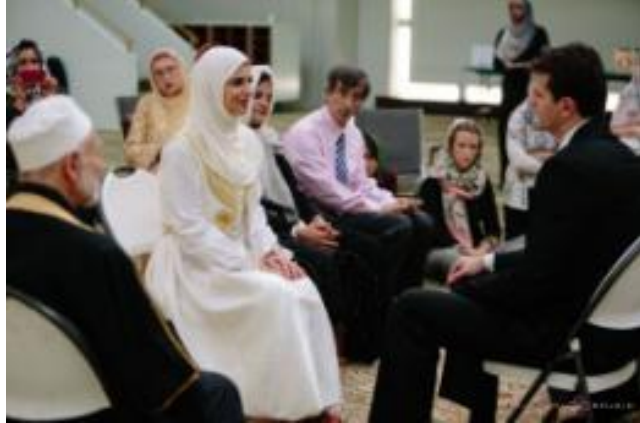

Figure 3. A marriage ceremony in ICC building [12] 
The facilities given by each institution are room facilities and services for mualaf. It can be seen from the process of activity in becoming a mualaf that a mualaf needs a practical room to practice the religious activities and the economic activities. For examples: practice to pray, to read Qur'an, to write Arabic letter, entrepreneur, etc. As supporting facilities, mualaf also needs a library and a living place.

1. There are some methods to handle the psychological effect for mualaf, i.e: personal approach method, speech method, khalaqah method, consultation and advocation method, audio-visual method.

\section{Personal Approach Method}

In this method, the guide makes a straight connection and dialogue to the mualaf in person. They give explanations and solutions for the problems in religion point of view.

\section{Speech Method}

The speech content is the things that are acceptable for a mind, and easily to understand by mualaf. The location, situation, and condition should feel comfortable for the mualaf.

\section{Khalaqah Method}

This method is similar to the speech method, but this method uses dialogue between the guide and the mualaf. So there will be questions and answers.

\section{Consultation and advocation method}

This method could be done together with the personal approach. The advice given to them to find the solution of their problems have to be delivered without making a conflict that probably happens.

\section{Audio Visual Method}

The audiovisual method is used for the new knowledge to be easier to understand. So for that reason, the facilities related to this activity should be available.

2. Sustainable architecture is focused on social, economical, and ecological principle that support the mualaf activities

It needs a unity of room, time, and user to create an environment condition that supports a comfort place to socialize. Sustainable by Design also keep trying to increase the life quality, promote the local and global balance, promote the economic welfare, also give an opportunity to do some activities together with the society.

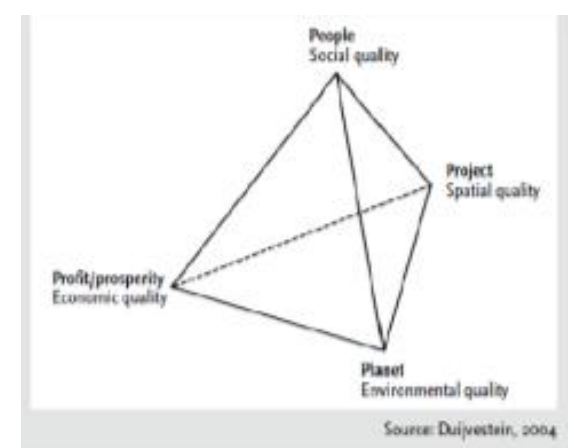

Figure 4. Conceptual Framework for Sustainalbility [13]

The basic principle for sustainable architecture, i.e: (1) the use of building material is for harnessing the local resources (energy conscious concept); (2) the use of natural building material (ecology benign materials); (3) Concern the user of the building in the designing process (respect for users); (4) design the building that support the energy efficiency principles; (5) minimize the design effect that harm the site and the environment (respect for site); (6) design a building that have a concern with the local environment, like the local climate (working with climate); (7) do the holistic approach that combine all of the design principles and ecological aspect; (8) prior the conservation and recycled material (recycled conceptminimising new resources); (9) minimize the use and dependency to the active energy system by changing it with another sources (like solar power, wind power, and the others); and (10) design a building with a high flexibility, so it can be used for various activities [14].

The application of sustainable architecture concept can be found in Greenlight House building in Copenhagen.

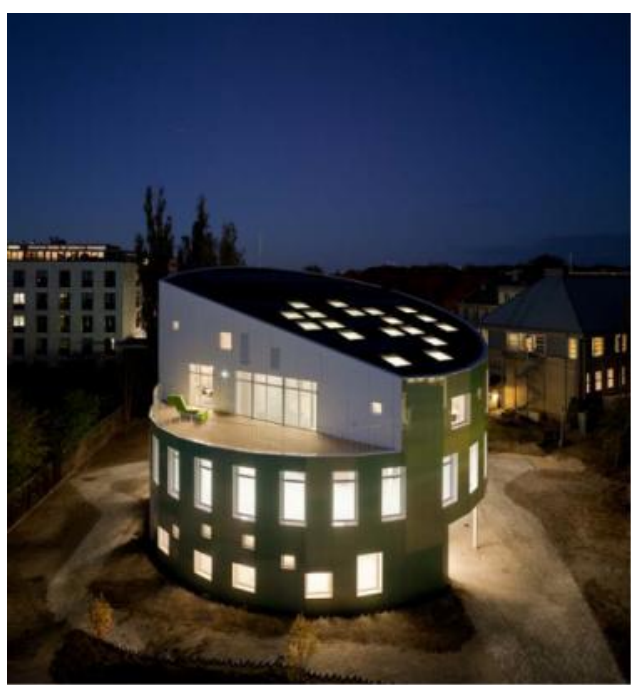

Figure 5. A night view of Greenlight House [15]

Greenlight House is a sustainable building that has a high, open, and wide ceiling as a space to enter light and air. The idea of the form of this building came from the adaptation with the local climate condition. For example, the use of sunlight as an energy source in 
the building. The round shape of this building is to spread the heat around the building surface, and the sloping roof is to apply the solar panel into the building to receive the sunlight as an energy. The holes in the curved walls are optimized as a ventilation. The location of the holes creates a cross ventilation. It can minimize the use of Air Conditioning (AC) in hot hours. The other things that also be a consideration to design this building are daylight, heat accumulation, construction cooling, hybrid ventilation, LED lighting in daylight control, and the efficiency energy of mechanic ventilation. Moreover, the daylight system in Greenlight House is very optimized, because the unmonumental round shape gives an opportunity for light to enter every room.

Furthermore, the facade of Greenlight House building uses the Swiss fiber construction which is a composite building material that consists of $30 \%$ glass and $70 \%$ polymer. This material consists of two components that have a strong quality from the other component. It is difficult to combine the composite material in some application feature with a conservative material like glass, metal, aluminum, and wood. It is because of the light weight of the Swiss fiber that has a strong high power and the wide of the plastic component.

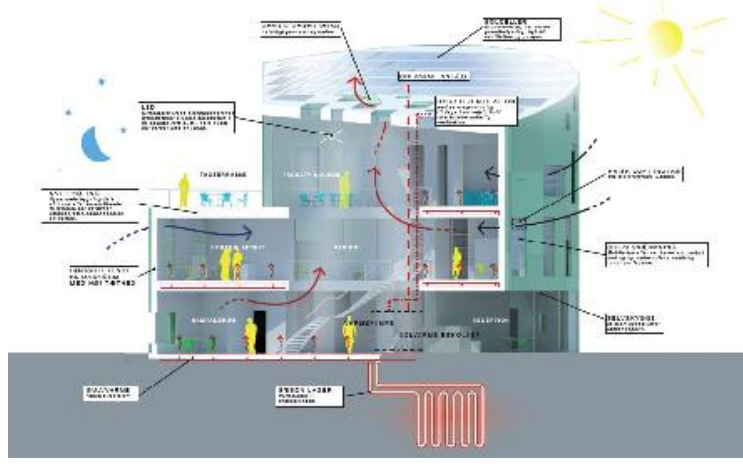

Figure 6. Energy concept that is applied in the operation of Greenlight House[15]

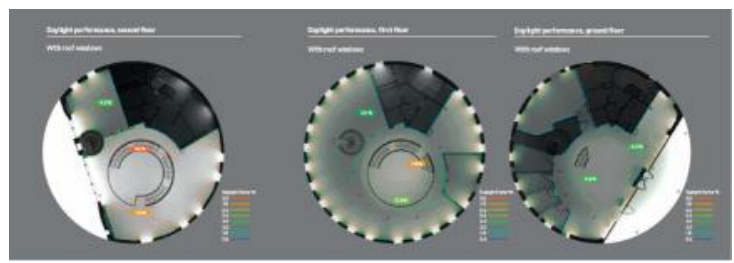

Figure 7. Daylight system analysis[15]

Greenlight House also applies a social value in its design, in addition to the application of the ecological principle. It can be seen in the facilities in the building. The interior design uses a circle room partition that shows a harmony of the relationship between the users of the room. The orange color of the sofa gives an impression of a spirit of communication between users. In a circle room with a few elbows and many soft edging creates a calm and flexible room. The room creates a free impression. That kind of room can provide a positive impact to mualaf psychology. It is needed to a guidance for mualaf.

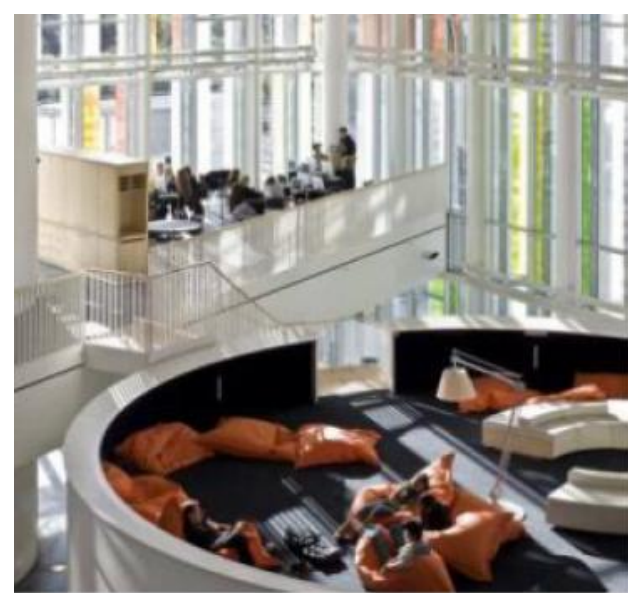

Figure 8. the common room in Greenlight House, Copenhagen [15]

\section{DESIGN RECOMMENDATION}

After studying the design of mualaf center and sustainable building, the design recommendation of Mualaf Center can be arranged. The design recommendation is to pay attention to the facilities needed by mualaf to get a mental and economic guidance. The facility needed is an Islamic boarding school to be used as a temporary living place for mualaf to be guided. By living in a boarding school, mualaf will be separated from the previous life where they got the stress, discrimination, or expulsion. It can help them to get rid of the trauma of a bad social environment. The other facility that supports the guidance activity is a mosque, where its function is not only for prayer but also for another activity that is related to mualaf education, like to learn how to pray, to pledge Shahadat, etc. Furthermore, there will be a common room to keep a contact with each other. For a no-Moslem that is still undergoing the ta'aruf process, can follow a class in the classroom. To complete the facilities, an auditorium is needed. This auditorium will not only be a practical room but also can be a place to hold a seminar. Moreover, other rooms that can support the mualaf center are administration room, study room, and library.

It is not easy to design a mualaf center that applies the principle of sustainable architecture, because it is related to economic, social, and ecological principles. To apply the ecological principle, the design of mualaf center needs to pay attention to the local 
climate, like building orientation, building coverage, roof, shading, and also the choice of small modular building material to avoid a machine to apply it. Furthermore, to harmonized the building with the environment, the use of local material and traditional construction need to be more concerned.

To influence someone psychology, the geometry form used in this building has to be flexible to pay more attention to the mualaf psychology that usually be depressed. It is also needed to provide a room that can create a calm and humble atmosphere, like the use of light blue color in the building. That kind of room is needed to create a communication between users, especially the mualafs.

It needs to pay more attention to the local climate, such as wind and sun. It can give an influence to the building design, especially in determining the form and dimension of the openings to let the daylight comes into the room. The use of daylight can decrease the energy used in the building so the operational cost will be low.

The low cost is also related to the use of natural lighting, air management, cross ventilation, and much more related to the indoor air quality. In the other hand, to represent the peculiarity of some culture also depends on the application of reduce-reuse-recyclereplace in the building material construction and the cultivation of energy, water, and waste. The sustainable architecture also identical with the green open area because this area will have many benefits, especially for the environment. So in order to design a sustainable architecture, an architect has to follow the nature condition, so the design will not ruin the nature.

\section{CONCLUSION}

The mualaf center in Malaysia is a building that will be a place of the center of information about Islam for the people who wants to learn about Islam. It will be a destination where people gives questions, needs a guidance and a protection, and also strengthen the mualaf rule, so the design will be adapted to the functional needs of mualaf and the administrator. By integrating the design requirements with the sustainable architecture design principles, the design of mualaf center will be appropriate with the need of mualaf because sustainable architecture pays attention to the relationship between building and nature, building and human as a social creature, and building and the economic life of the human. This design also will create a comfort room for people and can show that Islam is a gracious religion.

\section{REFERENCES}

[1] M. I. A. R. Al Marbawi, Kamus Idris Al-Marbawi (Arab-Melayu). Malaysia: Darul Nu'man, 1950.
[2] T. Hakiki and R. Cahyono, "Komitmen Beragama pada Muallaf ( Studi Kasus pada Muallaf Usia Dewasa )," vol. 4, no. 1, pp. 0-8, 2015.

[3] A. N. Baits, "Bagaimana Cara Masuk Islam," Konsultasi Syariah, 2014. [Online]. Available: https://konsultasisyariah.com/21860bagaimana-cara-masuk-islam.html. [Accessed: o8-Jan-2016].

[4] Muslim, "the Hadith," in 257, .

[5] A. Amir, "Bilangan Mualaf Di Malaysia Lebih Ramai Daripada Catatan Rasmi," 2015. [Online]. Available: http://www.ukm.my/news/Latest_News/bilang an-mualaf-di-malaysia-lebih-ramai-daripadacatatan-rasmi/. [Accessed: 08-Jan-2016].

[6] J. F. Kerry, "Country Reports on Human Rights Practices for 2015," Bureau of Democracy, Human Rights and Labor, 2015. [Online]. Available: http://www.state.gov/j/drl/rls/hrrpt/humanrigh tsreport/index.htm\#wrapper. [Accessed: 08Jan-2016].

[7] M. N. R. \& A. R. Farahwahida Mohd Yusof, Arieff Salleh Rosman, Azmi Shah Suratman, "Faktor dan Cabaran Pertukaran Agama dalam Kalangan Masyarakat Melayu-Islam di Malaysia," J. Teknol., vol. 59, pp. 41-50, 2012.

[8] M. Aishah, I. Junaida, A. J. Muna, S. R. M. D, and K. Jusoff, "Conversion Patterns among Mualafs at Pusat Bimbingan Islam Sultan Abdul Halim Mu'azam Syah Negeri Kedah Darul Aman (Pusba)," Elixir Soc. Sci., vol. 34, pp. 2509-2511, 2011.

[9] "Islamic Cultural Center of New York," 2015. [Online]. Available: http://www.nycarts.org/organizations/54433/islamic-culturalcenter-of-new-york. [Accessed: 08-Jan-2016].

[10] ICCNY, “Islamic Cultural Center,” 2012. [Online]. Available: http://www.iccny.us/Gallery.htm. [Accessed: 08-Jan-2016].

[11] W. Hu, "Rebuilding a Space for Prayer and Culture," The New York Times, New York, 2012.

[12] Gulnara Studio, "Modern Muslim Wedding, Islamic Cultural Center, New York: Parisa and Vedad," Gulnara Studio. [Online]. Available: https://www.gulnarastudio.com/weddings/par isa-vedad-part-one-islamic-cultural-center-nyc/. [Accessed: 08-Jan-2016]. 
[13] V. Gruis and H. Visscher, Sustainable Neighbourhood Transformation. Amsterdam: IOS Press BV, 2006.

[14] A. Y. Permana, "Eco-architecture Sebagai Konsep Urban Development di Kawasan Slums dan Squatters Kota Bandung," no. September, pp. 1-11, 2012.
[15] "Green Light House Presentation," 2009. [Online]. Available: greenlighthouse.ku.dk. [Accessed: 08-Jan-2016]. 